\title{
Library Orientation for Asian College Students
}

In an effort to determine what kind of library orientation is most needed by Asian students in American academic libraries, the author interviewed sixty Asian students from twenty different countries at the East-West Center, University of Hawaii, plus eleven faculty and staff members. These students cited fifteen special difficulties they had experienced in using the university library, and they made twelve suggestions for improving library orientation. General problems of Asian students are discussed, and programs for library instruction, on both graduate and undergraduate levels, are described. The author concludes with specific recommendations.

$\mathrm{T}$

HE ADMISSION of international students in growing numbers to American universities has brought about increased concern for their unique orientation problems in university libraries. Almost nothing on this subject, however, has appeared in library literature to date.

\section{Difficulties of Asian Students}

According to Verner, Far Eastern students are likely to experience more than the usual trouble orienting themselves, because liberal arts training in Asia often does not cover a wide range of Western history, literature, and the social sciences. ${ }^{1}$ Theirs is a problem of catching up. More specifically, instruction in library resources deals with books almost all of which are new to Asians; Americans have at least heard of many

${ }^{1}$ Mathilde M. Verner, "Far East Students in American Library Schools," Journal of Education for Librarianship, IV (Fall 1963), 59-68.

Miss Lewis is reference librarian at Stetson University in DeLand, Florida. of the most used reference works.

Experience at the University of $\mathrm{Ha}$ waii library has shown that the Asian's reading speed in English is frequently less than half that of the average American student; oral comprehension of the Asian student is often slower in the same ratio.

Since many Asian students in the United States are frequently mature professional persons, there are emotional and personal feelings of pride or shame involved in learning the strange symbols and routines involved in research techniques. Unfamiliarity with American ways in general and of American academic methods in particular constitute the large overshadowing problems for the Asian student, of which library orientation is only a segment.

Experience working extensively with Asian students at the University of Hawaii contributed the following insights on the basis of the problem:

1. Libraries in Asia are different. Many are small and have a large per- 
centage of outdated books. Public libraries in the Western sense frequently do not exist. Bibliographical tools in common use here may not be available there. The percentage of books in English is frequently low. In some countries, students even have to pay a library fee so that the library can buy books.

2 . The idea of library service is different. There is little concept of service to the public. Often the library simply provides a place to study.

3. The concept of higher education is different. Much greater reliance is placed there upon a single text or a few books on reserve. Students are accustomed to being handed the book they need. Independent study is largely unknown; instead, the professor in the classroom is paramount, and the library is peripheral.

4. The Asian student brings some misconceptions about libraries. In some countries, college instructors are paid to teach by the hour, so they may instruct twenty-five hours per week. Thus they are too busy to grade papers, must use their old lecture notes, and are not seen in the library by their students. No wonder, then, that the Asian student may consider the library unimportant.

In general, Asians do not understand that reference librarians are there to help them, and that they should ask for assistance. They will look for what they want in the card catalog, but they are also likely to give up if the answer to their need is not found there.

Since Asian students have been accustomed to using few books, they usually think only a certain title will do. It does not readily occur to them to substitute if the volume originally sought is unavailable. They are accustomed to single textbooks and rote learning.

Most Asian student problems parallel those of American students, but some are accentuated. Ramifications of thorough use of the card catalog are troublesome, especially under subject head- ings. Different classification systems in the United States, notably the Library of Congress, are often confusing to the newcomer. One reference librarian reported that many graduate students expect everything on a country to be under the country name in the cataloge.g., art and education in Thailand to be under "Thailand."

\section{Program at the University of HawaiI}

The University of Hawaii, with its large enrollment of Asian students and its strategic location, has done much pioneer work in the field. What has been done at this institution, therefore, assumes more than local significance. Affiliated with and on the Manoa campus of the University is the federallysupported East-West Center, which, through its varied program, works to promote mutual understanding among the peoples of Asia, the Pacific, and the United States. Many students come as grantees who otherwise could not afford the opportunity.

The English Language Institute is part of the Department of English as a Second Language. All nonnatives are examined upon arrival by an extensive battery of tests. Some foreign students, such as Canadians, are found to be able to compete equally and are exempted from the ELI program. The library gives special instruction to ELI classes. The institute schedules visits to the library, and the reference librarians give instruction adapted to the level and interests of the group. When possible, groups return for a second period of instruction.

Many Asian students come to the University of Hawaii through the East-West Center, and this agency schedules tours of the library for its grantees. The center has found many students unaccustomed to the self-service aspect of open stacks and to such a large library. Small groups of up to eight are set up for the 
tours, arranged according to interests.

A complete and ambitious program was developed at the university's Orientation Center for Fulbright grantees. It evolved over a period of years, but in 1966 a short course in library research was given to a group of fifty-eight. These students were divided by their academic fields of interest into five study sections-two in the social sciences, two in science, and one in the humanities. The classes met eight times for one hour and twenty minutes per session. The general sequence of activity in each session was: (1) presentation of the lesson, (2) student examination of the reference materials covered, and (3) assignment of individual problems for student work under supervision. The text was Cook's New Library Key. ${ }^{2}$ Each student prepared a short bibliography on his chosen topic, an outline, and one or two pages of sample text including footnotes. He presented an oral report to the class on his paper and took a quiz on library terms and abbreviations. The students uniformly praised the program and termed it very helpful, though demanding. By September the group dispersed to forty-four universities.

A feature of instruction effectively used in 1965 was that students submitted general questions; one instructor looked for the answers before the group while another gave a running commentary on what sources were being consulted.

In working with these Fulbright scholars, the inadequacy and unreliability of then existing library tests was discovered, as they applied to international students. Therefore, Shiro Saito and Floyd Cammack devised the American Library Information Test for Foreign Students. ${ }^{3}$ This was used both as pre-

\footnotetext{
${ }^{2}$ Margaret Gerry Cook, The New Library Key (2d ed., N. Y.: H. W. Wilson, 1963).

${ }^{3}$ Shiro Saito and Floyd Cammack, American Library Information Test for Foreign Students (Honolulu: University of Hawaii, 1965).
}

test and final examination. The test itself consists of general questions, parts of a book, the card catalog, general reference books, periodical indexes, and reference materials by subject areas. Questions are multiple choice, and the test has no time limit. Its validity for Asian students was checked by translating it into Japanese and Chinese and administering the Far Eastern versions to students from those countries. There was only a negligible difference in the results.

\section{INTERVIEWS WITH STUDENTS}

Against this background of experimentation and development on the University of Hawaii campus, the present author proceeded to interview a sample of Asian students enrolled there. Structured interviews were used, and each interview was fully written up a short time later. Questions used covered their home environment, library experience prior to college, academic background, and library experience at the University of Hawaii.

A total of sixty Asian students-fifty girls and a control group of ten menwere interviewed. Among the girls, seventeen countries were represented-Afghanistan, Australia, Fiji, Hong Kong, India, Indonesia, Japan, Korea, New Guinea, Okinawa, Pakistan, Philippines, Samoa, Singapore, Taiwan, Thailand, and Vietnam. In the control group of ten men, six countries were represented: two each from Indonesia, Pakistan, and the Philippines; and three additional countries were added to the list, with two students from Tonga and one each from Malaysia and Laos. Thus, a grand total of twenty countries in Asia and the Pacific areas were sampled in the survey.

\section{Difficulties Reported by Students}

The students' difficulties in using the library were reported as follows, listed 
in decreasing order of frequency. It should be noted that fourteen newly arrived students had not yet used the library and therefore had no difficulties to report:

1. Book not in place on shelf. (17)

2. Reference books hard to use. (10)

3. Changing classification from Dewey to LC. (9)

4. Loan period too long. (7)

5. Not enough copies of required books. (6)

6. Disorder in reserve room. (3)

7. Disruption caused by move to new library. (3)

8. Difficulty using card catalog. (2)

9. Natives beat Asians to the books. (2)

10. Restrictions on taking books out. (2)

11. Layout of library confusing. (2)

12. Open shelves unfamiliar. (2)

13. Not enough books owned by library on subject. (2)

14. Trouble using machines. (1)

15. Fine slips sent out without checking shelf. (1)

It is probable that the interviewees tended to minimize their difficulties. When asked if they had experienced difficulty using the library, students tended at first to say "No," but when asked a specific question there often followed admission of trouble.

Their answers therefore must be evaluated. They commonly spoke of having used public libraries and open stacks in their home countries, but it was clear from the discussion that few had experienced them as we know them. Many interviewees spoke of the helpfulness of the librarians, in contrast to their previous experience in their home countries. More than one student's feeling was summarized by a man from Tonga who said, "Difficulties are not bad if you win in the end."

\section{Student Suggestions}

All interviewees tried to be helpful when asked for suggestions for improving library orientation for Asian students. What they said is listed below, in decreasing order of frequency:

1. Require tours in small groups, stressing practical aspect. (14)

2. Provide more copies of books. (7)

3. Shorten loan period. (7) Lengthen loan period. (2)

4. Distribute layout maps of library. (6)

5. Give instruction in classes of major department only. (5)

6. Get friend to show student around individually. (5)

7. Seek help from librarian. (3)

8. Require a non-credit short course on use of library. (3)

9. Distribute explanation of classification system. (2)

10. Librarian should help student by assembling best books in field. (1)

11. Each department should have its own library. (1)

12. Library assignment should be required of all students in ELI. (1)

\section{Conclusions}

What, then, are the best ways to help the newly arrived Asian student in his library orientation? Are there any firm conclusions to be drawn from the comments and insights of these students and the staff who work with them?

First, it should be stated that there appears to be no one solution, easy or difficult; there is no magic panacea. The matter is a complicated one, involving not only the development of library skills but also total adjustment to the American academic environment and to life in a new land. Asians, perhaps more than any other group of foreign students, are faced with tremendous adjustment problems. They are confronted by 
strange food, different mores, new emphases in the classroom, and separation from home and friends. Orientation to the library is only a part-although an important part-of the student's total adjustment to his new academic milieu.

Fundamental to success is a thorough knowledge of English. In spite of careful screening and testing prior to arrival, most Asians come to the American college campus with at least minor, often serious, deficiencies in English. Frequently the student's language courses in his home country were taught by natives whose knowledge and accent were imperfect. Therefore, the Asian student, even with a number of credit hours on his transcript, is likely to be inadequately prepared for the American college classroom. It is often imperative, therefore, that he take a lightened course load at first, and receive some special English instruction.

The librarian requires an understanding of his problems. Special library instruction for foreign students may be advisable. Care must be taken not to try giving them too much information too fast. This is a major reason for instructing them apart from American students. The usual single library orientation period for new students is likely only to add confusion and frustration to foreign students included in it. Individual exceptions to this rule can, of course, be made in cases where language is no handicap. By and large, however, it seems well to give library instruction to foreign students separately from Americans.

A required course in the use of the library, including a study of reference books and bibliographies, has long been advocated by many librarians. This seems highly desirable in the case of Asian students, but it must be admitted that academic pressures make this idea difficult to implement, even to sell to the teaching faculty. Perhaps a compromise solution would be a voluntary offering of such a course at night, making it available to people in the surrounding community as well as to college students.

Individual help of the Asian student by the librarian is essential and vital. The "Big Brother" system is good and should be encouraged where possible. There is the danger, admittedly, that sometimes it may result in the blind leading the blind. The function of the reference librarian should be stressed to Asians; subtly he ought to make sure the students know how to use the reference tools they are shown. The librarian needs to sense their difficulties as well as to listen to their requests.

On the other hand, the Asian student must not be coddled. He must learn to compete equally, so he must gradually be helped to help himself. A student's complete dependency upon the reference librarian to do his research for him is to be avoided as being a disservice to him. He must be taught to look upon the location of suitable material as an important part of research; in time, the shorter the better, he must learn to do this on his own. If ever the reference librarian needed to be a teacher and a judge of students' capabilities and potential, it is at this point.

Above all, the Asian student needs encouragement. The librarian's task is to make him feel welcome, to give him confidence in himself. Unobtrusively he should be praised for what he does right. Care must be taken to cast no aspersions on his intelligence or previous education. Librarians are dealing here with people who may be psychologically in a state of tension, feeling uncertain of themselves, a little afraid of failure. They want to do well, to be accepted, to work very hard if necessary to attain their goals. In a strange land they are very eager and serious of purpose. If Americans can boast a superior background knowledge of libraries, Asians have many qualities, which, giv- 
en time and opportunity to develop, tial; it is the privilege of the librarian may well flower into real research prow- to assist in its development. ess. They bring with them great poten-

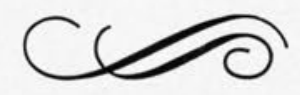

